\title{
SOCIAL VENTURE BUSINESS MODEL ARCHETYPES FIVE VEHICLES FOR CREATING ECONOMIC AND SOCIAL VALUE
}

\author{
JENNIFER L. WOOLLEY \\ Santa Clara University \\ Santa Clara, California, U.S.A. \\ jwoolley@scu.edu
}

\author{
ALBERT V. BRUNO \\ Santa Clara University \\ Santa Clara, California, U.S.A. \\ abruno@scu.edu
}

\author{
ERIC D. CARLSON \\ Santa Clara University \\ Santa Clara, California, U.S.A. \\ ecarlson@scu.edu
}

\begin{abstract}
Social ventures balance the economic and social dimensions of value creation to alleviate the problems created by shared collective issues. While much is known about economic value creation in conventional firms, little empirical work has focused on social ventures. As the number of social entrepreneurs continues to increase, the challenge of creating both economic and social value has emerged as an important research topic. In this article, we examine 124 social ventures from around the world to gain insight into ways social ventures pursue economic and social value creation. Five social venture business model archetypes emerge from the data. We conclude with implications for both theory and practice, and promising areas for future research.
\end{abstract}




\section{INTRODUCTION}

Social ventures have sparked considerable interest among organizational theorists and practitioners alike due to the recent increase in social entrepreneurship around the world and the novelty of their objectives. While social ventures have existed for decades, the awarding of the Nobel Peace Prize to Muhammad Yunus in 2006 for his work in pioneering the field of microfinance for women in poverty brought immediate and widespread attention to social venturing. The enormous reported success of Yunus' Grameen Bank, with a 98.6\% repayment rate (Yunus, 2007), has garnered the attention of entrepreneurs and corporations alike. In fact, social entrepreneurs have been described as "the vanguard (of) worldwide transformation" to improve the quality of life and standard of living around the world (Zahra, Rawhouser, Bhawe, Neubaum, \& Hayton, 2008: 117).

The work to understand social ventures is a nascent yet promising endeavor (Dacin, Dacin, \& Matear, 2010; Short, Moss, \& Lumpkin, 2009). In this young area, many articles discuss the definition of social venture or social entrepreneur (Dacin et al., 2010; Dees, 1998; Mair \& Marti, 2006; Peredo \& McLean, 2006; Short et al., 2009; Zahra, Gedajlovic, Neubaum, \& Shulman, 2009). Short and colleagues (2009) found that $38 \%$ of conceptual social entrepreneurship articles written between 1991 and 2009 focused on descriptions or definitions of the construct. Those articles constituted $20 \%$ of all published social entrepreneurship research. However, as the field has progressed in exploring the scope of social entrepreneurship and the concepts therein, little empirical work has been published (Weerawardena \& Mort, 2006).

Scholars do agree on one topic - that the main distinguishing characteristics of social ventures are their funding or revenue sources and their missions. While social ventures tend to focus on social rather than economic goals (Mair \& Marti, 2006), it is not clear what differentiates these goals or their enactment. Explicating not only the objectives of these ventures but also the methods used to accomplish these objectives is important in the understanding of how social ventures relate to traditional ventures (Florin \& Schmidt, 2011). However, how social entrepreneurs assemble and employ resources to enact their missions remains unclear (Zahra et al., 2009).

In this article, we examine resource mobilization and mission enactment by asking 1) which business models do social ventures employ and 2) what is the relationship between an organization's business model and its social mission. Using a unique dataset of 124 early social ventures from around the world, we identify the most common business 
models used. Furthermore, we explore how these business models are employed to fulfill the goals of the venture, such as fighting poverty, increasing educational opportunities, and improving the environment. To do so, we focus on the sources of funding, revenue, missions, and locations of these social ventures to determine if patterns exist. By examining these characteristics of social ventures through exploratory factor analysis and descriptive statistics, we find five social venture business model archetypes. These archetypes provide insight into how the unique objectives of social ventures, one of the very aspects that makes them so intriguing, are reached in a world heavily influenced by profit-maximizing concepts and mindsets.

The main contribution of this article is its empirical investigation of commonalities among social ventures and the identification of distinguishing characteristics. Literature in this area has largely treated social ventures as being homogeneous, with any variation found in the entrepreneur himself/herself (Zahra et al., 2009). We build on previous research by shifting the focus from the definition and recognition of the opportunity by the social entrepreneur to the enactment of the opportunity by the social enterprise itself. By identifying social venture business model archetypes, we build on the work defining a typology of social entrepreneurs (Zahra et al., 2009), and show how social ventures attempt to create and capture economic and social value.

The article proceeds with a discussion of the literature on social entrepreneurship and social ventures. In the following section, the setting for the study and the methods are described. Findings start with identifying business models and progress to identifying relationships between business models and venture missions. We then discuss the implications of these findings for social entrepreneurs. Specifically, we contend that social entrepreneurs can benefit by knowing which business models are most suitable for scalable social ventures in their market sectors. Social entrepreneurs who understand their business model alternatives in the context in which their social ventures operate can improve their decision-making skills and the chances for the survival of their organizations. We conclude with opportunities for further research in this burgeoning area and a discussion of implications for the stakeholders of social entrepreneurs.

\section{SOCIAL PROBLEMS AND BUSINESS SOLUTIONS}

Social entrepreneurship increasingly garners interest from researchers and the public alike; however, a deeper understanding is stymied by the contention surrounding its definition. Work on social ventures has 
engaged in various debates on its definition, especially the characteristics that differentiate social entrepreneurship from traditional forms of business enterprise (Austin, Stevenson, \& Wei-Skillern, 2006; Dacin et al., 2010; Zahra et al., 2009). Definitions range from organized philanthropy (Van Slyke \& Newman, 2006) to organizations aimed at progressive social transformations (Martin \& Osberg, 2007). Definitions often refer to a "double bottom line" that emphasizes both social and economic dimensions (Emerson \& Twersky, 1996). Some include a "triple bottom line" that portrays social, economic, and environmental dimensions of the enterprise (Desrochers, 2010). While we appreciate the veracity of the core ideas in these descriptions, there is but one unifying theme throughout: social ventures are "organizations seeking business solutions to social problems" (Thompson \& Doherty, 2006: 362). ${ }^{1}$

In their attempt to clarify this cloudy territory, Zahra and colleagues (2009: 519) attempted to integrate the variety and diversity of definitions into one: "Social entrepreneurship encompasses the activities and processes undertaken to discover, define, and exploit opportunities in order to enhance social wealth by creating new ventures or managing existing organizations in an innovative manner." Similarly, Dacin and colleagues (2010) find that the definitions of social entrepreneurship tend to converge on four key factors: 1) characteristics of individual social entrepreneurs, 2) operating sector, 3) processes and resources used, and 4) primary mission and outcomes. Of these four factors, the authors find the last two-use of resources and primary mission-as having the potential for the most significant variation. Thus, we focus this study on these two factors: processes/resources used and primary missions/outcomes.

Social ventures attempt to alleviate problems caused by shared collective issues by using methods traditionally applied to commercial businesses (Austin et al., 2006; Dacin et al., 2010; Meyskens, Robb-Post, Stamp, Carsrud, \& Reynolds, 2010). As such, social ventures use resources to maintain operations and achieve their goals (Barney, 1991; Daft, 2009) much like conventional enterprises do (Dacin et al., 2010). However, while the literature on conventional entrepreneurship emphasizes sources of funding, including loans, capital from friends and family and venture capital investment during their formative years, studies have not determined the extent to which these same capital sources are available for and utilized by social ventures. In fact, it was not until the mid-1990's that selected venture capital firms with their own social mission targeted funds for social entrepreneurs. With increased numbers of for-profit and

${ }^{1}$ We acknowledge that the definition of social venture remains contentious. For reviews of the literature, please see Zahra et al., 2009; Short et al., 2009; Dacin et al., 2010. 
non-profit organizations entering the social arena, social ventures have started to explore alternatives to obtaining the funding they need (Dees, 1998). Similarly, social ventures compete with conventional ventures to capture value, both social and economic. These facts raise questions: From where do social ventures obtain their funding and how are they employing these funds to reach their objectives? In essence, what are the characteristics of social venture business models?

The term "business model" gained popularity in the 1980's with the increased use of spreadsheets that enabled business modeling to become standard practice in developing and executing a business strategy. Since that time, a number of articles have been written that generally address the topic of business models. One of the earliest efforts to define business models was proposed by Timmers (1998: 4) as "an architecture for the product, service, and information flows, a description of the benefits for the business actors involved, and a description of the sources of revenues." In his analysis of e-commerce, he used a two-dimensional model of functional integration and degree of innovation to identify eleven Internet business models. Similarly, Amit and Zott (2001: 494-495) examined e-businesses and proposed defining a business model as "transaction content, structure and governance so as to create value through the exploitation of business opportunities." Through the years, work by scholars and practitioners building on these frameworks has culminated in identifying three main differentiating elements of business models: resources, value proposition, and profit formula (e.g., Chesbrough \& Rosenbloom, 2002; Malone et al., 2006).

As mentioned earlier, one area in which conventional and social ventures differ is in their missions. In general terms, the mission of a conventional venture is to maximize shareholder wealth through value creation and appropriation. Social ventures maximize social benefit by creating social value (Mair \& Marti, 2006). Thus, the missions of social ventures center on alleviating problems of society and community, both narrowly and broadly defined. In the case of the former, the mission may address the needs of a rural African village. In the case of the latter, the mission may aspire to improve the sustainability of the planet. These are shared collective issues that influence many people. Thus, in identifying business models of social ventures, the profit formula focusing only on pecuniary gains may not capture how an organization is providing communal value. For social ventures, the profit formula element of the business model should be replaced with a broader characterization of value such that social business models will focus on resource use, the value proposition, and social value creation and capture. For example, Florin and Schmidt (2011) found that social entrepreneurs create hybrid 
organizations using business model innovations to enact social and environmental goals.

As discussed, the two main characteristics of social ventures with the most potential for variation are the processes of resource orchestration and primary mission identification. These overlap the social business model in that the mission of a social venture often describes the value proposition and value creation mechanisms; therefore, a powerful differentiator of one social venture from another will be the business models that they employ.

Social ventures "are sustainable only through the revenue and capital that they generate; thus, their financial concerns must be balanced equally with social ones" (Dacin et al., 2010: 45; see also Webb, Kistruck, Ireland, \& Ketchen, 2009). In other words, to be sustainable, a social venture must not only create social value for the collective good, but also create economic value for sustaining the organization's continuing operations. Because conventional organizations have only one of these constraints, this dual requirement is peculiar to social ventures. However, while research in social entrepreneurship focuses on the individuals that create these organizations and their motives (Spear, 2006; Zahra et al., 2009), we have little insight into how these entrepreneurs attempt to enact their missions. The processes by which social entrepreneurs enact their missions are important since the balance between the economic and social aspects of a social venture's value creation is critical to its success. While theoretically intertwined, the relationships among a social venture's business models, missions, locations, and founding date remain unclear. In this article, we examine the relationship between business model and mission. We expect that our results should inform prospective social entrepreneurs who are confronted with the challenge of creating and executing business models that support organization sustainability and serve their missions. The more efficiently the social entrepreneur iterates his/her venture to the appropriate business model, the more impactful the venture will be.

\section{METHODS}

\section{Setting}

To examine the business models of social ventures, we use the data from social ventures participating in the Global Social Benefit Incubator $\left(\mathrm{GSBI}^{\mathrm{TM}}\right)$ at Santa Clara University. Since 2003, the GSBI has helped social businesses develop sustainable business models through an intensive two-week residential program augmented by online collaborative education and intensive individual mentoring. Through 2010, 124 organiza- 
tions had graduated from the GSBI program. Of these organizations, a third operate in South East Asia (mainly India), 28\% operate in Africa and the Middle East, $15 \%$ in South America, 5\% are located in Asia, and the rest operate in the Middle East, United States, or multiple areas. Table 1 summarizes the locations of our sample. The GSBI chooses organizations for participation based on the organization's social-oriented mission, commitment to the social mission, potential benefit to society, and the likely scalability of the social venture. While the database contains a bias toward successful organizations, such data were chosen for that very reason - they provide detailed information about the business models that were effective for social venture survival. Over $90 \%$ of the participating ventures were still operating in 2012.

\begin{tabular}{|c|c|c|}
\hline Region & Count & Percentage \\
\hline Asia & 6 & $4.80 \%$ \\
\hline SouthEast Asia & 41 & $33.10 \%$ \\
\hline South America & 18 & $14.50 \%$ \\
\hline Africa and Middle East & 34 & $28.20 \%$ \\
\hline Multiple regions & 24 & $19.40 \%$ \\
\hline Total & 124 & \multicolumn{1}{|l}{} \\
\cline { 1 - 2 }
\end{tabular}

Table 1. Sample of social ventures by geographic region

\section{Data}

Extensive archival data were collected for each of the organizations. Data included business plans, financial statements, correspondence, and websites totaling approximately 3,000 pages. These documents were open coded by at least two researchers for several variables, including source of funds, mission, organization's location (country and region), year founded, and year dissolved (if applicable). Open coding entails analyzing each line of data to determine labels, definitions, or events related to the research question (Strauss \& Corbin, 1998). Since the initial funding of all 124 organizations was contributed (usually at the beginning of operations as start-up funding), the classification of funds was based on the primary drivers in the business models in long-term operations. After coding 15 organizations, researchers compared results and discussed similarities and differences for revenue and funds flow. Collectively, the researchers determined a final set of codes for each variable and then recoded the data accordingly.

The organizations were coded by their missions using the Millennium Development Goals (MDG), a categorization created by the United 
Nations with the objective of ending poverty by the year 2015 (United Nations, n.d.). There are eight MDG, the first seven of which are relevant to social venture missions. The eight MDG are 1) eradicate extreme poverty and hunger, 2) achieve universal primary education, 3) promote gender equality and empower women, 4) reduce child mortality, 5) improve maternal health, 6) combat HIV/AIDS, malaria, and other diseases, 7) ensure environmental sustainability, and 8) develop a global partnership for development. The eighth is an institutional goal and not relevant to individual social ventures; thus, it was dropped from the analysis and not coded.

Some of the social ventures from the GSBI do not have missions described by the MDGs. These organizations tend to have missions related to the MDG, but broader in scope. For example, multiple organizations promote equality, but not exclusively for women. Reexamining the missions of the organizations in the sample led to the creation of six overarching goal categories: 1) poverty, 2) education, 3) equality, 4) health, 5 ) environment, and 6) other. The "other" category included ventures that did not fit into the preceding set of categories such as safety inspections of buildings, technology development, and translation services. All organizations were coded dichotomously for these six mission categories, each with its separate variable. Table 2 summarizes the number of ventures associated with each mission.

The context of an organization not only depends on its geographical location but also the time at which it was founded. Work in organizational demography and population ecology has generally found that the age of an organization influences its chances for survival (Hannan, 1998). At the same time, "the kinds of organizations that emerge reflect the social structures of the founding period" (Hannan, 1998: 132). Specifically, the types and structures of organizations that are socially acceptable reflect their institutional environments, which change over time (Meyer $\&$ Rowan, 1977). As social ventures have gained legitimacy in both the social and theoretical realms (Dart, 2004; Peredo \& MacLean, 2006), options available to them change as well. For instance, as mentioned, venture capital firms only started dedicating funds to social ventures in the 1990's; thus, venture capital was not widely available for social ventures before that time. It would follow that the business models used by social ventures would change over time as well.

To capture the context and timing of the venture, we included variables on the venture's location and date founded. The ventures operate in 34 countries including India, Nigeria, South Africa, Kenya, Indonesia, Cambodia, Mexico, and Argentina. The firms were recoded using binary variables representing six regions: Asia, South East Asia, South America, 
Africa, the Middle East, and the US. ${ }^{2}$ The ventures were coded by year founded, which ranged from 1920 to 2009. The sample was then split into three cohorts using the creation of the MDG in 2000 as the basis for defining the first cohort and then splitting the remaining ventures into two roughly equal groupings. With an even split between the organizations founded in the years 2000 to 2009, the last year an organization in the sample was founded, each cohort included approximately a third of the sample. Binary variables represent each of the three cohorts: before 2000, 2000-2004, and 2005-2009.

\begin{tabular}{|c|c|c|}
\hline Mission & Count & Percentage \\
\hline Environment & 19 & $15.30 \%$ \\
\hline Poverty & 67 & $54.00 \%$ \\
\hline Education & 16 & $12.90 \%$ \\
\hline Health & 13 & $10.50 \%$ \\
\hline Equity & 5 & $4.00 \%$ \\
\hline Other & 4 & $3.20 \%$ \\
\hline
\end{tabular}

Table 2. Summary of missions for social ventures in the sample

\section{Analysis}

To analyze the business models of these ventures, we used exploratory factor analysis (EFA). EFA is a data reduction method that identifies the number of factors (latent variables) that effectively represent the data (Kline, 1998). A factor or latent variable is an unobserved variable that is not measured directly by observed variables (Kelloway, 1998). In an exploratory factor analysis, the observed variables are considered linear combinations of factors (Suhr, 2003). EFA determines the number of factors that linearly reconstruct the observed variables (STATA, 2001). Each observed variable is correlated to or "loads onto" each factor and the factor loadings are the correlation between a variable and a factor. The model of exploratory factor analysis is

$$
\mathrm{Y}=\mathrm{X} \beta+\mathrm{E}
$$

where $\mathrm{Y}$ is a matrix of observed variables, $\mathrm{X}$ is a matrix of factors, $\beta$ is a matrix of factor loadings, and $\mathrm{E}$ is a matrix of errors called uniqueness values (Suhr, 2003).

${ }^{2}$ All ventures in the US operate in multiple countries. 
In STATA, a tetrachoric correlation matrix was created since the variables were coded dichotomously (Uebersax, n.d.). Next, we ran an EFA based on this correlation matrix. The initial model included the maximum number of factors, which showed an extreme scenario to encompass all variance of the variables. However, the extreme case usually includes too many factors to effectively reduce the data since few variables load onto each factor. Next, we set upon determining the number of factors to effectively reduce the data but explain as much of the variance in the model as possible. These EFA results indicate the eigenvalue of each factor or the amount of variance explained by each factor. In this case, factors are used to represent business models. One method of determining the number of factors to retain is to perform a scree test by plotting the eigenvalues and determining the number of factors in the plot that represent the highest variance (Cattell, 1966). The results indicated that no fewer than four factors should be retained in the model. Next, we ran four EFA models retaining four, five, six, and seven factors. In each model, we identified which factor each variable loaded on to the strongest (highest). We then looked at patterns emerging from the factors. Models with six and seven factors resulted in factors with no income or revenue variables loading highly, thus rendering the models unproductive for this study. The models with four and five factors each resulted in factors loaded highly with at least one income or revenue variable, a mission, and a location. The model with five factors contained variables with lower uniqueness values than the models with four factors, which indicates a better fit with the data. To eliminate bias that arises from researcher arbitrariness, both four and five factor models were examined in light of theory regarding social entrepreneurship. This effort resulted in the retention of the five-factor model. Next, the models were rotated and factor loadings were determined. ${ }^{3}$ From this process, archetypes emerged from the data depicting the most highly correlated funding or revenue, mission, location, and founding date. These archetypes are discussed in the next section.

\section{FINDINGS}

\section{Revenue and Funding}

Social ventures obtain financial resources mainly through contributions and earnings from governments, donors, impact investors or customers. GSBI ventures used one or multiple methods to obtain funds, including grants, donations, sales, transaction fees, licensing royalties, franchise royalties, or subscriptions. In total, $39 \%$ of the ventures relied

${ }^{3}$ All models, scree plot, and rotations are available from the authors upon request. 
on contributions, $82 \%$ earned an income, and $21 \%$ used a combination of both. Table 3 summarizes these methods and their representation in the sample. Half of the ventures obtained revenue directly from the sales of products or services. Across all ventures, $44 \%$ offered products and $42 \%$ offered services. Ventures also used a per transaction fee to earn revenue ( $26 \%$ of sample). Additionally, $21 \%$ and $24 \%$ of the ventures obtained funding from grants and donations, respectively.

\begin{tabular}{|c|c|c|}
\hline Main Resources & $\begin{array}{c}\text { Number of } \\
\text { Social Ventures }\end{array}$ & $\begin{array}{c}\text { Percentage of } \\
\text { Sample }\end{array}$ \\
\hline Sales & 62 & $50.00 \%$ \\
\hline Products & 55 & $44.40 \%$ \\
\hline Services & 52 & $41.90 \%$ \\
\hline Coop & 1 & $0.80 \%$ \\
\hline Grants & 26 & $21.00 \%$ \\
\hline Donations & 30 & $24.20 \%$ \\
\hline Per transaction fee & 32 & $25.80 \%$ \\
\hline License/franchise & 7 & $5.60 \%$ \\
\hline Subscriber/access & 8 & $6.50 \%$ \\
\hline Other & 3 & $2.40 \%$ \\
\hline
\end{tabular}

Table 3. Summary of GSBI social ventures by major financial sources

Note: The total does not equal $100 \%$ since some firms are equally split between two major financial sources.

Ventures obtained contributed capital from individuals, missionaligned foundations, or government entities that provide funds without receiving a product or service in return. Contributed capital ventures rely on these parties to provide funds in the form of grants and donations. For example, the Comite para Democratizacao da Informatica de Brasilia (CDI-DF) provides free computers, software, training, and technical maintenance in Brazil and is funded by monetary and product donations. Meds and Food for Kids, a provider of highly nutritious foods to malnourished Haitian children, was initially funded through a World Bank Grant before being funded by donations. Organizations also obtain donations as a percentage of third-party sales.

Earned income ventures provide products or services as a means to fund their social agenda. The income is based on products or services with an "economic buyer" that may or may not be the direct beneficiary of the products/services. Ventures earned income from sales of products 
or services, coop fees, per transaction fees, licenses, franchises, and subscriptions. Half of earned income ventures did so through direct sales of products or services, often making the goods that they sold. Alternatively, ventures sold goods produced by third parties. Organizations also earned an income through transaction fees (26\%), subscriptions (7\%), and licensing and franchising fees (6\%). Examples include b2bpricenow. com which provides an online portal for rural farmers to trade goods and charges a fee per transaction, Video Volunteers which utilizes earned income from licensing fees when it helps create separate video businesses in the slums of Brazil, and Transclick which uses a subscription-based income model providing real-time translation on phone calls.

A small group of five ventures was composed of hybrid models with two (or more) legal entities, at least one of which was based on contributed capital drivers and (at least) one based on earned income drivers. For example, Synergo Arts helps artists and artisans around the world with ergonomic work solutions such as the ergonomic weaving benches it creates and distributes. It finances its activities by collecting donations and providing consulting services for a fee.

\section{Business Model Archetypes}

As described, funding, missions, location, and year of founding were examined using EFA. Comparing the sources of funding to primary missions and location of the social ventures also showed several patterns. Descriptive statistics and a correlation matrix of the variables are shown in Tables 4 and 5, respectively. The factor analysis with five factors retained is shown in Table $6 .{ }^{4}$ Each of the five factors represents a social venture archetype, summarized in Table 7 . The five social venture archetypes are 1) Government Contributions, 2) Private Contributions, 3) Product Sales, 4) Service Offering, and 5) Licensing and Franchising.

Social ventures using the Government Contributions business model archetype obtain funds primarily through grants and donations from their national governments and international government entities such as the United Nations. These ventures most often support equality-related missions in multiple regions, with an emphasis on South America. The ventures relying on government support are mainly those founded before 2000 .

${ }^{4}$ Resulting model: $X^{2}(378)=9919.98 p<0.0000$ 


\begin{tabular}{|c|c|c|c|c|}
\hline Variable & Mean & SD & Min & Max \\
\hline Products & 0.44 & 0.50 & 0 & 1 \\
\hline Services & 0.42 & 0.50 & 0 & 1 \\
\hline Coop & 0.01 & 0.09 & 0 & 1 \\
\hline Grants & 0.21 & 0.41 & 0 & 1 \\
\hline Donations & 0.24 & 0.43 & 0 & 1 \\
\hline Sales & 0.50 & 0.50 & 0 & 1 \\
\hline Transaction & 0.26 & 0.44 & 0 & 1 \\
\hline License/franchise & 0.06 & 0.23 & 0 & 1 \\
\hline Subscriber & 0.07 & 0.25 & 0 & 1 \\
\hline Other & 0.02 & 0.15 & 0 & 1 \\
\hline Mission-Environment & 0.15 & 0.36 & 0 & 1 \\
\hline Mission-Poverty & 0.54 & 0.50 & 0 & 1 \\
\hline Mission-Education & 0.13 & 0.34 & 0 & 1 \\
\hline Mission-Health & 0.11 & 0.31 & 0 & 1 \\
\hline Mission-Equity & 0.04 & 0.20 & 0 & 1 \\
\hline Mission-Other & 0.03 & 0.18 & 0 & 1 \\
\hline Asia & 0.05 & 0.22 & 0 & 1 \\
\hline SouthEast Asia & 0.33 & 0.47 & 0 & 1 \\
\hline South America & 0.15 & 0.35 & 0 & 1 \\
\hline Africa and Middle East & 0.27 & 0.45 & 0 & 1 \\
\hline Multiple regions & 0.19 & 0.40 & 0 & 1 \\
\hline Found before 2000 & 0.38 & 0.49 & 0 & 1 \\
\hline Found 2000-2004 & 0.34 & 0.48 & 0 & 1 \\
\hline Found 2005-2009 & 0.28 & 0.45 & 0 & 1 \\
\hline
\end{tabular}

Table 4. Descriptive Statistics

The Private Contributions business model archetype social venture obtains funds primarily through individuals, investment organizations, and private foundations. These funds are usually in the form of grants, cash donations, product donations, the donation of a percentage of the donor's sales, and equity investment. The primary missions of Private Contributions ventures tend to focus on health. Social ventures relying on private contributions tend to be located in Africa and the Middle East, but are also found in South East Asia. These tend to be founded between the years 2000-2004. 


\begin{tabular}{|c|c|c|c|c|c|c|c|c|c|c|c|c|c|}
\hline & Variable & $\mathbf{1}$ & 2 & 3 & 4 & 5 & 6 & 7 & 8 & 9 & 10 & $\mathbf{1 1}$ & 12 \\
\hline 1 & Government & 1 & & & & & & & & & & & \\
\hline 2 & Products & -0.51 & 1 & & & & & & & & & & \\
\hline 3 & Services & 0.16 & -0.49 & 1 & & & & & & & & & \\
\hline 4 & Coop & -0.25 & 0.50 & -0.43 & 1 & & & & & & & & \\
\hline 5 & Grants & 0.56 & -0.31 & 0.06 & -0.31 & 1 & & & & & & & \\
\hline 6 & Donations & 0.37 & -0.43 & -0.28 & -0.35 & 0.36 & 1 & & & & & & \\
\hline 7 & ales & -0.29 & 0.87 & -0.51 & 0.53 & -0.32 & -0.37 & 1 & & & & & \\
\hline 8 & Transaction & 0.11 & -0.59 & 0.75 & -0.42 & -0.03 & -0.24 & -0.57 & 1 & & & & \\
\hline 9 & License/franchise & -0.26 & 0.08 & 0.06 & -0.24 & 0.12 & -0.06 & -0.11 & 0.27 & 1 & & & \\
\hline 10 & Subscriber & 0.36 & -0.31 & 0.57 & -0.24 & 0.12 & 0.11 & -0.26 & 0.05 & -0.31 & 1 & & \\
\hline 11 & Other & -0.19 & 0.20 & 0.10 & -0.07 & -0.31 & -0.41 & 0.18 & 0.26 & -0.19 & -0.21 & 1 & \\
\hline 12 & Mission-Environment & -0.36 & 0.24 & -0.05 & -0.14 & -0.14 & 0.14 & 0.29 & -0.18 & 0.29 & 0.12 & -0.23 & 1 \\
\hline 13 & Mission-Poverty & -0.02 & 0.07 & 0.06 & 0.44 & -0.13 & -0.25 & 0.11 & 0.18 & -0.10 & 0.03 & 0.52 & -0.31 \\
\hline 14 & Mission-Education & 0.49 & -0.12 & 0.20 & -0.24 & 0.29 & 0.23 & -0.07 & $|-0.06|$ & -0.42 & 0.48 & -0.26 & -0.19 \\
\hline 15 & Mission-Health & 0.28 & 0.04 & -0.31 & -0.16 & 0.32 & 0.31 & 0.02 & -0.21 & 0.26 & -0.33 & -0.17 & -0.16 \\
\hline 16 & Mission-Equity & -0.14 & -0.47 & -0.05 & -0.16 & 0.23 & 0.22 & -0.53 & 0.11 & $-0.17 \mid$ & -0.23 & -0.09 & -0.13 \\
\hline 17 & Mission-Other & -0.27 & 0.08 & 0.06 & -0.11 & -0.35 & -0.37 & -0.07 & 0.16 & 0.45 & -0.24 & -0.05 & -0.12 \\
\hline 18 & Asia & -0.27 & -0.06 & 0.19 & -0.09 & -0.41 & 0.16 & 0.01 & 0.04 & -0.26 & 0.39 & -0.05 & 0.20 \\
\hline 19 & SouthEast Asia & 0.16 & -0.06 & 0.10 & 0.54 & 0.05 & -0.15 & 0.02 & 0.08 & -0.07 & 0.06 & -0.25 & 0.11 \\
\hline 20 & South America & 0.01 & 0.06 & -0.21 & -0.32 & 0.28 & 0.20 & 0.02 & -0.12 & 0.07 & -0.44 & 0.27 & 0.07 \\
\hline 21 & Africa and Middle East & -0.12 & -0.08 & 0.12 & 0.39 & -0.13 & 0 & -0.02 & 0.06 & -0.14 & 0.21 & -0.43 & 0.16 \\
\hline 22 & Multiple regions & 0.11 & -0.13 & -0.02 & -0.36 & 0.17 & 0.07 & -0.18 & 0.04 & 0.33 & 0.13 & -0.32 & -0.01 \\
\hline 23 & Found before 2000 & 0.25 & -0.32 & 0.01 & -0.41 & 0.30 & 0.43 & -0.42 & -0.12 & 0.24 & 0.27 & -0.46 & 0.12 \\
\hline 24 & Found 2000-2004 & -0.11 & 0.16 & -0.10 & 0.56 & -0.05 & -0.06 & 0.24 & -0.20 & -0.10 & -0.13 & -0.33 & -0.01 \\
\hline 25 & Found 2005-2009 & -0.10 & 0.09 & 0.13 & -0.25 & -0.12 & -0.25 & 0.13 & 0.32 & -0.09 & -0.07 & 0.64 & 0.02 \\
\hline
\end{tabular}

Table 5a. Correlation Matrix

The Product Sales business model archetype is not simply about selling a venture's own product, but includes the sale of third party products in resale and wholesale. Product Sales social ventures focus on an education mission, primarily in Asia. These ventures are usually those founded in the latest cohort, between the years 2005 and 2009. 


\begin{tabular}{|c|c|c|c|c|c|c|c|c|c|c|c|c|c|c|}
\cline { 2 - 8 } & Variable & $\mathbf{1 3}$ & $\mathbf{1 4}$ & $\mathbf{1 5}$ & $\mathbf{1 6}$ & $\mathbf{1 7}$ & $\mathbf{1 8}$ & $\mathbf{1 9}$ & $\mathbf{2 0}$ & $\mathbf{2 1}$ & $\mathbf{2 2}$ & $\mathbf{2 3}$ & $\mathbf{2 4}$ & $\mathbf{2 5}$ \\
\hline 13 & Mission-Poverty & 1 & & & & & & & & & & & & \\
\hline 14 & Mission-Education & -0.31 & 1 & & & & & & & & & & & \\
\hline 15 & Mission-Health & -0.30 & -0.18 & 1 & & & & & & & & & & \\
\hline 16 & Mission-Equity & -0.29 & -0.13 & -0.10 & 1 & & & & & & & & & \\
\hline 17 & Mission-Other & -0.28 & -0.15 & -0.10 & -0.04 & 1 & & & & & & & & \\
\hline 18 & Asia & 0.07 & 0.21 & -0.27 & -0.20 & -0.21 & 1 & & & & & & & \\
\hline 19 & SouthEast Asia & 0.21 & -0.19 & -0.05 & 0 & -0.38 & -0.24 & 1 & & & & & & \\
\hline 20 & South America & -0.19 & -0.05 & 0.10 & 0.21 & 0.15 & -0.31 & -0.39 & 1 & & & & & \\
\hline 21 & Africa and Middle East & 0.11 & -0.01 & -0.10 & -0.01 & -0.43 & 0.54 & 0.60 & -0.60 & 1 & & & & \\
\hline 22 & Multiple regions & -0.43 & 0.22 & 0.11 & 0.12 & 0.37 & -0.27 & -0.33 & -0.29 & -0.35 & 1 & & & \\
\hline 23 & Found before 2000 & -0.37 & 0.11 & 0.13 & 0.09 & 0.23 & 0.08 & -0.14 & 0.21 & 0.03 & 0.12 & 1 & & \\
\hline 24 & Found 2000-2004 & 0.08 & 0.07 & -0.16 & -0.04 & 0.04 & -0.08 & 0.21 & -0.05 & 0.10 & -0.11 & -0.48 & 1 & \\
\hline 25 & Found 2005-2009 & 0.17 & -0.12 & 0.10 & -0.01 & -0.38 & 0.08 & -0.07 & -0.18 & -0.03 & 0.05 & -0.48 & -0.51 & 1 \\
\hline
\end{tabular}

Table 5b. Correlation Matrix (continued)

The Service Offering business model archetype includes not only simple service transactions (fee-for-service), but also includes vendors that are membership or subscription based, or ventures that provide access to markets such as a coop or online marketplace. For example, Digital Divide Data provides IT services to libraries, publishers, businesses, and institutions for a fee, and provides job opportunities by training young Cambodians and Laotians. E-shop Africa provides access to a web-based marketplace for African artisans. Service Offering ventures focus on alleviating poverty in many areas including Asia, South East Asia, Africa, and the Middle East. The Service Offering archetype highlights the relationship between earning an income through services and the mission of poverty alleviation. This finding is consistent with Prahalad (2005), Hart and Christensen (2002), and others who argue that poverty reduction can be accomplished through traditional market (earned income) approaches. Service Offering ventures are among the youngest, being founded between the years 2005 and 2009. 


\begin{tabular}{|c|c|c|c|c|c|c|}
\cline { 2 - 6 } \multicolumn{1}{c|}{} & \multicolumn{6}{c|}{ Factor } \\
\hline Variable & $\mathbf{1}$ & $\mathbf{2}$ & $\mathbf{3}$ & $\mathbf{4}$ & $\mathbf{5}$ & Uniqueness \\
\hline Government & 0.58 & 0.18 & 0.21 & -0.52 & 0.05 & 0.32 \\
\hline Products & -0.79 & -0.34 & 0.14 & 0.11 & 0.29 & 0.14 \\
\hline Services & 0.40 & 0.56 & -0.46 & 0.24 & -0.12 & 0.24 \\
\hline Coop & -0.78 & 0.18 & 0.41 & -0.13 & -0.34 & 0.06 \\
\hline Grants & 0.57 & -0.14 & 0.26 & -0.46 & -0.11 & 0.37 \\
\hline Donations & 0.55 & -0.11 & 0.47 & -0.19 & 0.21 & 0.38 \\
\hline Sales & -0.80 & -0.21 & 0.21 & -0.01 & 0.36 & 0.14 \\
\hline Transaction & 0.34 & 0.37 & -0.69 & 0.10 & -0.35 & 0.13 \\
\hline License/franchise & 0.11 & -0.45 & -0.19 & 0.44 & -0.38 & 0.42 \\
\hline Subscriber & 0.40 & 0.62 & 0.14 & 0.23 & 0.35 & 0.27 \\
\hline Other & -0.37 & 0 & -0.78 & -0.37 & 0.26 & 0.04 \\
\hline Mission-Environment & -0.12 & -0.08 & 0.21 & 0.51 & 0.23 & 0.62 \\
\hline Mission-Poverty & -0.44 & 0.42 & -0.28 & -0.34 & -0.14 & 0.42 \\
\hline Mission-Education & 0.40 & 0.23 & 0.28 & -0.06 & 0.46 & 0.50 \\
\hline Mission-Health & 0.17 & -0.43 & 0.19 & -0.31 & -0.01 & 0.65 \\
\hline Mission-Equity & 0.34 & -0.10 & -0.05 & -0.17 & -0.35 & 0.72 \\
\hline Mission-Other & 0.04 & -0.50 & -0.29 & 0.55 & -0.28 & 0.28 \\
\hline Asia & -0.04 & 0.52 & 0.06 & 0.42 & 0.50 & 0.30 \\
\hline SouthEast Asia & -0.21 & 0.48 & 0.33 & -0.16 & -0.54 & 0.30 \\
\hline South America & 0.12 & -0.63 & -0.12 & -0.31 & 0.11 & 0.47 \\
\hline Africa and Middle East & -0.15 & 0.68 & 0.40 & 0.22 & -0.17 & 0.27 \\
\hline Multiple regions & 0.40 & -0.32 & -0.05 & 0.31 & 0 & 0.64 \\
\hline Found before 2000 & 0.63 & -0.20 & 0.28 & 0.28 & 0.06 & 0.41 \\
\hline Found 2000-2004 & -0.35 & 0.05 & 0.42 & 0.02 & -0.38 & 0.55 \\
\hline Found 2005-2009 & -0.16 & 0.18 & -0.61 & -0.25 & 0.35 & 0.39 \\
\hline
\end{tabular}

Table 6. Factor Analysis Results with Five Factors Retained

Number of observations $=124$

Retained factors $=5$

Number of parameters $=115$

LR test: independent vs. saturated: $\operatorname{chi} 2(300)=0.0004104$ Prob $>$ chi $2=0.000$ 


\begin{tabular}{|c|c|c|c|}
\hline Archetype & Resource Source & Location & Founded \\
\hline \multirow{2}{*}{$\begin{array}{l}\text { I. Government } \\
\text { and Equality }\end{array}$} & 1 - Government grants & $\begin{array}{l}\text { South } \\
\text { America }\end{array}$ & \multirow{2}{*}{$\begin{array}{l}\text { before } \\
2000\end{array}$} \\
\hline & 2 - Donations & $\begin{array}{l}\text { Multiple } \\
\text { Regions }\end{array}$ & \\
\hline \multirow{3}{*}{$\begin{array}{l}\text { II. Private } \\
\text { Contributions } \\
\text { and Health }\end{array}$} & 1 - Foundation grants & Africa & \multirow{3}{*}{$\begin{array}{l}2000- \\
2004\end{array}$} \\
\hline & 2 - Donations & $\begin{array}{c}\text { Middle } \\
\text { East }\end{array}$ & \\
\hline & $\begin{array}{l}3 \text { - Contributions plus } \\
\text { product or services } \\
\text { (hybrid) }\end{array}$ & SE Asia & \\
\hline \multirow{3}{*}{$\begin{array}{l}\text { III. Product } \\
\text { Sale for } \\
\text { Education }\end{array}$} & $\begin{array}{l}4-\text { product sales-own } \\
\text { product }\end{array}$ & Asia & \multirow{3}{*}{$\begin{array}{c}2005- \\
2009\end{array}$} \\
\hline & $\begin{array}{l}5 \text { - product sales-third } \\
\text { party product }\end{array}$ & $\begin{array}{c}\text { South } \\
\text { America }\end{array}$ & \\
\hline & $\begin{array}{c}6-\text { product sales_student } \\
\text { produced }\end{array}$ & & \\
\hline \multirow{3}{*}{$\begin{array}{l}\text { IV. Services to } \\
\text { Fight Poverty }\end{array}$} & $\begin{array}{c}\text { - Own services (sales by } \\
\text { transactions) }\end{array}$ & $\begin{array}{l}\text { Asia \& SE } \\
\text { Asia }\end{array}$ & \multirow{3}{*}{$\begin{array}{l}2005- \\
2009\end{array}$} \\
\hline & $\begin{array}{c}8-\text { Membership (fee to } \\
\text { join / subscription based) }\end{array}$ & Africa & \\
\hline & $\begin{array}{c}9-\begin{array}{c}\text { Access vendors (coop } \\
\text { or market access) }\end{array} \\
\end{array}$ & $\begin{array}{c}\text { Middle } \\
\text { East }\end{array}$ & \\
\hline \multirow{2}{*}{$\begin{array}{l}\text { V. Licensing } \\
\text { and } \\
\text { Franchising } \\
\text { for the } \\
\text { Environment }\end{array}$} & $\begin{array}{l}10 \text { - License or franchise } \\
\text { product }\end{array}$ & \multirow{2}{*}{$\begin{array}{l}\text { Multiple } \\
\text { Regions }\end{array}$} & \multirow{2}{*}{$\begin{array}{l}\text { before } \\
2000\end{array}$} \\
\hline & $\begin{array}{l}11 \text { - License or franchise } \\
\text { services }\end{array}$ & & \\
\hline
\end{tabular}

Table 7. Social Venture Archetype Summary

The Licensing and Franchising business model archetype includes the licensing of products and the franchising of business processes and models. Franchising is becoming a more frequent business model for social ventures (Tracey \& Jarvis, 2007). In our sample, such social ventures tend to have missions focused on the environment or issues not captured in the other categories. The Licensing and Franchising archetype is the most global of the ventures, often operating in multiple regions. The relatively global operations for this archetype follow the hypothesis, proposed by Zahra and colleagues, that "social ventures are likely to 
internationalize when they have or can develop particular capabilities that could be deployed to serve unique social needs" (Zahra et al., 2008: 125). Licensing and Franchising social ventures attend to issues common in many societies. For example, Meridian Design, Inc. tackles the problem of unclean water by designing and licensing its water purification technology, thus attending to an issue faced throughout the world. Similarly, Frost Protection Corporation licenses its agriculture products that help farmers protect crops from cold temperatures.

\section{DISCUSSION}

Organizations range from purely economics-driven to purely charitydriven (Margolis \& Walsh, 2003). Social ventures and entrepreneurs lie in the middle of this spectrum, attempting to bring together economic and social value creation (Dacin et al., 2010; Emerson \& Twersky, 1996). Social entrepreneurs often use business model innovations to incorporate social value creation into their strategic objectives (Florin \& Schmidt, 2011). However, within that portion of the spectrum consisting of social ventures, great heterogeneity remains. In this article, we attempt to shed some light on the types of social ventures by highlighting heterogeneity across mission and context. By examining a database of 124 social ventures that have participated in the GSBI over the past nine years, we find that the mission of a social venture is often tied to a particular business model, i.e., poverty and a services-based business model, or equality and a government support-based model. Furthermore, by examining patterns in capital, missions, and locations of social ventures through factor analysis, we find that not only are these elements related, but also that they can be summarized by five business model archetypes.

This study builds on institutional theory that seeks to understand how organizations are "imprinted" by their environment (e.g., Boeker, 1988; Johnson, 2007; Kriauciunas \& Kale, 2006). In their efforts to change their social or environmental contexts, social venture entrepreneurs are both constrained and enabled by that same context. Conventional ventures struggle with the same circumstances (Oliver, 1991); however, social ventures provide an extreme example. As such, social ventures may have a different yet equally complex set of environmental influences. Starting with the lack of traditional funding sources such as those focused on profit-maximization and available to for-profit firms, social ventures are directly and immediately influenced by their context.

This article contributes to entrepreneurship literature by focusing on how organizations enact their objectives. We show that social ventures use a subset of business models that are largely linked to their mission 
and environmental contexts. This finding raises questions: Are business models, funding sources, and objectives of conventional organizations similarly linked? What is the variance across cultural, institutional, conventional and social ventures? Similarly, in studying social ventures, scholars focus on ventures with a particular type of objective: social missions. In doing so, this work highlights the importance of a venture's objectives to its choice of business model. A better understanding of this relationship would be useful across the different types of ventures.

This study also extends our understanding of the range of social ventures. First, through an empirical study of social venture business models, missions, locations, and time of founding, we show both commonalities and differences among social ventures. We find that social ventures are not homogeneous as previously treated in the literature. Furthermore, the data shows that the relationships among these four constructs can be captured by five archetypes: Government Support, Private Contributions, Product Sales, Service Offering, and Licensing and Franchising. The archetypes help explicate the differences between social and conventional ventures, as well as how social ventures endeavor to achieve their economic and social objectives. Because these organizations represent a specialized sample of social enterprises that develop and scale, it is these types of organizations that offer the greatest promise for effectively addressing social issues. Knowledge gained from a study of these organizations can be useful for informing the vast majority of social ventures that are neither sustainable nor scalable. The archetypes developed here are based on relatively successful ventures-as mentioned, over $90 \%$ of this sample was still operating through 2012. It thus follows that nascent social entrepreneurs can look to these archetypes for guidance.

\section{Limitations and Future Research}

Empirical studies on social ventures are plagued with the difficulty of obtaining data and sample selection (Short et al., 2009). This study attempts to overcome these limitations by using data from participants in the GSBI. While archival and interview data were obtained for each venture, sample selection was limited to those ventures with a manager who knew about, applied for, and was selected for the program. This GSBI selection process may bias the sample toward successful or more developed ventures. In this vein, the sample represents only ventures with access to knowledge about the program and the means to apply, which requires literacy skills and Internet access. Therefore, ventures in remote areas without much external contact, those with poorly educated management, or those without the means to apply for the program are eliminated from inclusion. 
While we do not make claims as to the long-term effect of archetype choices, the sample does represent ventures able to acquire at least a minimum set of resources. Additionally, the GSBI program is limited to about 20 participants per year. As the program developed, however, competition increased; as a result, the later cohort may represent better prepared ventures. Despite these limitations, the study does capture an understudied aspect of social ventures: the ways social ventures seek their goals of economic and social value creation. The richness of the data allowed for the relationship between business models and social mission to emerge. The business model-mission relationship revealed in the study contributes to the growing body of literature on social ventures that seeks to understand how organizations embody more than economic goals.

One obvious area of investigation that is vital for social ventures is the extent to which business models and archetypes change over time. The rationale is that in most successful commercial ventures, business models tend to evolve over time as the nature of the marketplace and competitive environment change, and may need to be radically changed for survival or further growth (e.g., in the computer industry). We have anecdotal evidence from GSBI alumni that business evolution or radical change is equally likely in social ventures. It is possible that the S-curve is relatively flat for a longer period in the case of social ventures and that the time to "positive cash flow" and "break even" is longer (e.g., 7-10 years as opposed to $2-5$ years for pure profit maximizing enterprises). An investigation to test this type of hypothesis will require a comparative study between social ventures and conventional firms.

The most significant area for investigation is the extent to which certain social venture revenue models scale more successfully than others. Such studies must focus on the unit economics of the social venture. Since social ventures balance social and economic dimensions, determining the economic success of such ventures may be less relevant than determining their social impact; thus, we must first determine how we define success in the social realm. A related area of inquiry has to do with the extent to which the different types of business models are associated with various measures of double or triple bottom line performance metrics. In particular, does higher social value creation necessarily reduce financial performance, require contributed capital for positive cash flow, or require greater patience on the part of investors? Similarly, these questions highlight the need for studies on the value chains required for each archetype, the key income and expense drivers in each value chain, and whether simple value chains are more sustainable or scalable than complex ones. 
Social issues occur in every corner of the world. As organizations are imprinted with the context and conditions in which they are founded (Boeker, 1988; Stinchcombe, 1965), it follows that social ventures are imprinted with their locations as well. For one, the objective of the venture may be location dependent. For instance, some social issues are location dependent, such as Amazon forest conservation in South America or remote Internet access in rural locations. In addition, the social structure surrounding the venture may embody norms regarding the type of missions that are socially acceptable or legitimate (Carroll \& Hannan, 2000). Thus, location is an important factor in the creation of a social venture. The extent to which the context of the venture is related to the business model or mission remains an open question.

\section{CONCLUSION}

It is perhaps the socialness of social ventures that makes them so interesting. The organization and strategy field has focused on the economic ends of firms, classifying organizations chiefly as for-profit or not-for-profit. Recently, however, extensions of corporate social responsibility and, most recently, social entrepreneurship are a refreshing complexity to the field. Although not a new phenomenon, our understanding of the social side of organizations is limited. Examining social ventures is a promising area of research with implications for both theory and practice. Our focus on the relationships among business models, mission, location, and founding year seeks to explicate some of the confusion surrounding social ventures. As social ventures continue to multiply and evolve, research into the nature of these social ventures should provide useful guidance to social entrepreneurs. We build on previous research by shifting the focus from the definition and recognition of the opportunity to the enactment of the opportunity-in this case, business model archetypes.

\section{REFERENCES}

Amit, R., \& Zott, C. 2001. Value creation in e-business. Strategic Management Journal, 22(6-7): 493-520.

Austin, J., Stevenson, H., \& Wei-Skillern, J. 2006. Social and commercial entrepreneurship: Same, different, or both? Entrepreneurship Theory and Practice, 30(1): 1-22.

Barney, J. B. 1991. Firm resources and sustained competitive advantage. Journal of Management, 17(1): 99-120. 
Boeker, W. 1988. Organizational origins: Entrepreneurial and environmental imprinting at the time of founding. In G. R. Carroll (Ed.), Ecological Models of Organizations: 33-52. Cambridge, MA: Ballinger.

Carroll, G. R., \& Hannan, M. T. 2000. The demography of corporations and industries. Princeton, NJ: Princeton University Press.

Cattell, R. B. 1966. The scree test for the number of factors. Multivariate Behavioral Research, 1(2): 245-276.

Chesbrough, H., \& Rosenbloom, R. S. 2002. The role of the business model in capturing value from innovation: Evidence from Xerox Corporation's technology spin-off companies. Industrial and Corporate Change, 11(3): 529-555.

Dacin, P. A., Dacin, M. T., \& Matear, M. 2010. Social entrepreneurship: Why we don't need a new theory and how we move forward from here. Academy of Management Perspectives, 24(3): 37-57.

Daft, R. L. 2009. Organizational theory and design. Mason, OH: South-Western Cengage Learning.

Dart, R. 2004. The legitimacy of social enterprise. Nomprofit Management and Leadership, 14(4): 411-424.

Dees, J. G. 1998. Enterprising nonprofits: What do you do when traditional sources of funding fall short? Harvard Business Review, Jan/Feb: 55-67.

Desrochers, P. 2010. The environmental responsibility of business is to increase its profits (by creating value within the bounds of private property rights). Industrial and Corporate Change, 19(1): 161-204.

Emerson, J., \& Twersky, F. 1996. New social entrepreneurs: The success, challenge, and lessons of non-profit enterprise creation. San Francisco: Roberts Foundation.

Florin, J., \& Schmidt, E. 2011. Creating shared value in the hybrid venture arena: A business model innovation perspective. Journal of Social Entrepreneurship, 2(2): 165-197.

Hannan, M. T. 1998. Rethinking age dependence in organizational mortality. American Journal of Sociology, 104: 126-164.

Hart, S. L., \& Christensen, C. M. 2002. The great leap: Driving innovation from the base of the pyramid. MIT Sloan Management Review, Fall: 51-56.

Johnson, V. 2007. What is organizational imprinting? Cultural entrepreneurship in the founding of the Paris Opera. American Journal of Sociology, 113(1): 97-127.

Kelloway, E. K. 1998. Using Lisrel for structural equation modeling. Thousand Oaks, CA: Sage Publications.

Kline, R. B. 1998. Principles and practice of structural equation modeling. New York: The Guilford Press.

Kriauciunas, A., \& Kale, P. 2006. The impact of socialist imprinting and search on resource change: A study of firms in Lithuania. Strategic Management Journal, 27(7): 659-679.

Mair, J., \& Marti, I. 2006. Social entrepreneurship research: A source of explanation, prediction, and delight. Journal of World Business, 41(1): 36-44. 
Malone, T. W., Weill, P., Lai, R. K., D’Urso, V. T., Herman, G., Apel, T. G., \& Woerner, S. 2006. Do some business models perform better than others? MIT Sloan research paper no. 4615-06, MIT Sloan School of Management, Cambridge, MA.

Margolis, J. D., \& Walsh, J. P. 2003. Misery loves companies: Rethinking social initiatives by business. Administrative Science Quarterly, 48(2): 268-305.

Martin, R. L., \& Osberg, S. 2007. Social entrepreneurship: The case for definition. Stanford Social Innovation Review, Spring: 28-39.

Meyer, J. W., \& Rowan, B. 1977. Institutionalized organizations: Formal structure as myth and ceremony. American Journal of Sociology, 83(2): 340-363.

Meyskens, M., Robb-Post, C., Stamp, J. A., Carsrud, A. L., \& Reynolds, P. D. 2010. Social ventures from a resource-based perspective: An exploratory study assessing global Ashoka Fellows. Entrepreneurship Theory and Practice, 34(4): 661-680.

Oliver, C. 1991. Strategic response to institutional processes. Academy of Management Review, 16(1): 145-179.

Peredo, A. M., \& McLean, M. 2006. Social entrepreneurship: A critical review of the concept. Journal of World Business, 41(1): 56-65.

Prahalad, C. K. 2005. The fortune at the bottom of the pyramid: Eradicating poverty through profits. Philadelphia: Wharton School Publishing.

Short, J. C., Moss, T. W., \& Lumpkin, G. T. 2009. Research in social entrepreneurship: Past contributions and future opportunities. Strategic Entrepreneurship Journal, 3(2): 161-194.

Spear, R. 2006. Social entrepreneurship: A different model? International Journal of Social Economics, 33(5/6): 399-410.

STATA Press. 2001. Stata reference manual. College Station, Texas: Stata Corp.

Stinchcombe, A. L. 1965. Social structure and organizations. In J. G. March (Ed.), Handbook of organizations, 142-193. Chicago: Rand McNally.

Strauss, A., \& Corbin, J. 1998. Basics of qualitative research: Techniques and procedures for developing grounded theory (2nd ed.). Thousand Oaks, CA: Sage.

Suhr, D. D. 2003. Principal component analysis vs. exploratory factor analysis. Working paper, University of Northern Colorado, Greeley, CO

Thompson, J., \& Doherty, B. 2006. The diverse world of social enterprise: A collection of social enterprise stories. International Journal of Social Economics, 33(5/6): 361-375.

Timmers, P. 1998. Business models for electronic markets. Journal of Electronic Markets, 8(2): 3-8.

Tracey, P., \& Jarvis, O. 2007. Toward a theory of social venture franchising. Entrepreneurship Theory and Practice, 31(5): 667-685.

Uebersax, J. S. n.d. Introduction to the tetrachoric and polychoric correlation coefficients, www.john-uebersax.com/stat/tetra.htm (accessed March 24, 2011).

United Nations. n.d. Millennium Development Goals, www.un.org/ millenniumgoals (accessed October 1, 2010). 
Van Slyke, D. M., \& Newman, H. K. 2006. Venture philanthropy and social entrepreneurship in community redevelopment. Nomprofit Management and Leadership, 16(3): 345-368.

Webb, J. W., Kistruck, G. M., Ireland, R. D., \& Ketchen, D. J. 2009. The entrepreneurship process in base of the pyramid markets: The case of multinational enterprise/ nongovernment organization alliances. Entrepreneurship Theory and Practice, 34(3): 555-581

Weerawardena, J., \& Mort, G. S. 2006. Investigating social entrepreneurship: A multidimensional model. Journal of World Business, 41(1): 21-35.

Yunus, M. 2007. Creating a world without poverty: Social business and the world of capitalism. Perseus Book Group.

Zahra, S. A., Gedajlovic, E., Neubaum, D. O., \& Shulman, J. M. 2009. A typology of social entrepreneurs: Motives, search processes and ethical challenges. Journal of Business Venturing, 24: 519-532.

Zahra, S. A., Rawhouser, H., Bhawe, N., Neubaum, D., \& Hayton, J. 2008. Globalization of social entrepreneurship. Strategic Entrepreneurship Journal, 2(2): 117-131. 